\title{
The challenges of animal welfare in modern Brazilian poultry farming
}

\author{
Karina Suemi Sakamoto • Natália Cristina Benincasa - Iran José Oliveira da Silva iD. \\ Cristian Marcelo Villegas Lobos
}

\author{
KS Sakamoto - NC Benincasa - IJO Silva (Corresponding \\ author) \\ Departament of Biosystems Engeneering, University of São \\ Paulo (ESALQ/USP), Av. Pádua Dias, 11, 13418-900, \\ Piracicaba, São Paulo, Brazil. \\ email: iranoliveira@usp.br
}

\author{
CMV Lobos \\ Department of Exact Science, University of São Paulo \\ (ESALQ/USP), Piracicaba, São Paulo, Brazil.
}

Received: January 28, 2020 • Accepted: March 14, 2020 • Published Online: April 07, 2020

\begin{abstract}
The Brazilian poultry industry is undergoing a process of increasing rigor regarding production practices related to breeding and pre-slaughter operations since animal welfare is an extremely important subject that has received great attention in the developed countries. Brazil is one of the greatest producers of chicken meat, concerns have existed in the sense of adequacy to continue attending to the demand of export and maintenance of the position of leadership, in front of the other market players. One of the key points is the necessity to improve the intensive farming, which currently has many obstacles that prejudice the basic principles of animal welfare assurance. Relatively simple problems in handling animals, litter and equipment, as well as the lack of preventive maintenance in the facilities are the main ones responsible for the thermal discomfort and quality of life of these animals. Despite all the considerations raised, a large part of the Brazilian consumers is still unaware of intensive farming and the way animals are raising on the farm until their plates, being surrounded by myths and false beliefs. Therefore, the purpose of this review is to address the main critical issues affecting the welfare of broiler chickens in intensive commercial production.
\end{abstract}

Keywords: chicken litter, intensive production, thermal comfort

\section{Introduction}

Animals raised for commercial purposes are beings with the ability to feel pain, emotions and interact with the environment, being considered sentient. There are many definitions of the well-being, but perhaps the most complete and accepted in the scientific milieu is that of Broom (1986) who states that the well-being of an individual is his statement in relation to his attempts to adapt to his environment.
Intensive farming is the predominant structure in the production of chicken meat in Brazil. Advances in the field of genetics have brought benefits and productivity in strains that are better suited to the stages of the poultry industry. It is also noteworthy the advances in the production of vaccines and nutritional area, as well as improved environmental conditions, facilities and high-tech equipment. The different inputs suppliers are important links in the chain and generators of a significant part of the productivity gains in the poultry industry.

However, there is a challenge to be overcome, the way intensive poultry production will attend the requirements of BEA and loss mitigation. Therefore, the aim of this literature review is to address the main critical points that affect the welfare of broiler chickens in the commercial production systems.

\section{Losses before the broiler farm}

"Pre-portress" operations are all activities involving the transport of fertile eggs, the activities carried out in hatcheries and the transport of one-day-old chicks before they are housed in the farms. Several losses occur in this process. For example, the temperature oscillations in the load are harmful for the neonates, as they do not yet have a thermoregulatory system developed. Several losses occur in this process. For example, the temperature oscillations in the load are harmful to the neonates, because they do not have a thermoregulatory system developed. In addition, heat loss in the first days of life affects the acid-base balance of blood and body fluids, reducing maintenance energy and compromising growth (Abreu and Abreu 2011), consequently, these animals are highly dependent on the microclimate around.

Therefore, it is important to point out that losses are always present during the entire production cycle, but it is up 
to each integrator to closely review the operations performed in its integrated companies, to reduce them to the maximum extent.

\section{Losses at the broiler farm}

The term "inside the portress" refers to activities during raising the broilers on the farm, until the birds reach approximately 42 days old and are catching for slaughter. This topic will address the losses during the production of broilers on the farm and the factors related to them.

\section{Main injuries during raising of broiler chickens}

Contact dermatitis, breast blister and scratches are the main carcass lesions in broiler chickens, which are caused by improper handling during the farm period. Such lesions are positively related and can occur simultaneously, being associated mainly with litter quality (Saraiva et al 2016), so it is influenced by a complex interaction of several factors that involve the production system, genetics, stocking density, zootechnical index, flock health, nutrition and farm management (Menzies et al 1998; Nagaraj et al 2007).

Nutrition is important in the development of dermatitis since influencing the consistency of the feces and, consequently, the quality of the litter is related to the improvement of the quality and resistance of the skin (Shepherd and Fairchild 2010). In the study by De Jong et al (2015), reported a lower incidence of pododermatitis and hock burn injury in diets with low energy compared to high energy diets.

The weight of the birds may also influence the development of these lesions since lighter birds do not tend to present hock burns, whereas birds with moderate weight have mild injuries and pododermatitis, and heavier birds may present severe hock burn and breast injuries (Saraiva et al 2016).

The incidence of scratches may be affected by stocking density, the distance between feeders and drinkers, levels of bird activity, feed shortage, farm management, genetic of the birds, transportation, and crate density (Proudfoot 1973; Bilgili 1990; Frankenhuis et al 1991; Broom and Reefmann 2005).

The scratches may have a negative correlation with contact dermatitis, since birds with severe dermatitis in the legs have a lower locomotion ability (Kristensen et al 2006), being less active and lie down longer, being more susceptible to develop breast blister and less capable to scale or inflict scratches on other birds (Allain et al 2009).

\section{The broiler litter}

Many elements are involved in litter quality directly or influence flock health or behavior, such as temperature and relative humidity of the air indoor and outdoor, production system, season, genetic of the bird, house lighting, drinking system, litter management (material, depth and reuse of the litter), periods between flocks and nutrition (Bilgili et al 2009; Shepherd and Fairchild 2010; De Jong et al 2015).

Diseases that lead to diarrhea are potential contributors to worsening litter quality, such as intestinal coccidiosis caused by Eimeria maxima, Eimeria acervulina and Eimeria necatrix (Dunlop 2015).

The litter reuse should be carefully thought out, as the accumulation of waste and the lack of adequate management leads to the generation of gases from the microbial decomposition. Ammonia is a colorless gas and mucosal irritant that can injure the respiratory tract of birds. In addition, it predisposes to diseases and increases the risk of infections secondary to vaccinations.

High litter moisture is a multifactorial problem in poultry production (Van Der Hoeven-Hangoor et al 2014) affecting bird welfare, flock health, food security and productive efficiency (Dunlop 2015) defined as wet when it presents more than 25\% moisture (Collett 2012).

De Jong et al (2014) observed that very wet litters result not only in a greater number and severity of pododermatitis but also greater severity in hock burns, breast irritation, and dirtier plumage. These same authors found a higher incidence of scratches in groups of broilers raised in litters with low moisture. The justification presented for this observation is that broilers raised in litters with high moisture have greater problems of locomotion, preferring to rest and reducing their activity, as it was also justified by Vestergaard and Sanotra (1999), while the other broilers have more interaction, which leads to an increase in the number of scratches mainly on the thighs.

Although some authors claim that the quality of litter is the most important factor in pododermatitis generation, Kjaer et al (2006) suggest that pododermatitis has a relatively high heritability, and this problem should be included in genetic selection programs. According to Dawkins and Layton (2012), the association between management practices and genetics is an important tool to improve conditions related to the welfare of livestock animals, which according to Federici et al (2016) means that the resolution of welfare problems such as the incidence of injuries - can go beyond the actions performed by poultry companies through management practices.

It was noted that the litter quality worsens with the increase of the birds' weight; and pododermatitis lesions and walking ability get more severity, due to the increased pressure and the contact surface of the cushions with the litter (Costa et al 2014). Because fast-growing broiler tend to remain seated from the third week of age onwards, with the hock and breast in contact with the litter, increasing the incidence of dermatitis in these regions, which can cause pain and prevent access to the feeder and drinker, leading to lower 
body weight gain and bird performance (Allain et al 2009; Alvino et al 2009).

For these reasons, it is considered a challenge to keep the litter dry until the end of the production cycle. Because the birds grow and reach the slaughter weight, and the moisture and nutrients in the litter increase too. Thus, it is necessary a balance between the replacement of the litter, the cost of this exchange, and the availability of alternative substrates, in times of scarcity or difficult access (Bilgili et al 2009).

\section{Stocking density}

Stocking density is a critical factor in the poultry industry. It influences the economic return of broiler production since higher revenues can be obtained by placing more birds per square meter, and the costs of workers' wages, farm maintenance and inputs are diluted (Estevez 2007; Tsioris et al 2015) to the detriment of bird health and welfare. However, bird genetics, farm management, and environmental conditions should be considered to allow a BEA condition and good carcass quality (Moreira et al 2001).

In the literature, there are several international laws and protocols that recommend maximum stocking densities of $30 \mathrm{~kg} / \mathrm{m}^{2}$ to $42.5 \mathrm{~kg} / \mathrm{m}^{2}$ (EC 2007; Welfare Quality 2010; Switzerland 2011; New Zealand 2012).

The stocking density affects litter quality, carcass quality, and broiler performance. It generates increased the litter moisture and affects the severity of locomotor problems. In addition, they have a significant linear effect on the generation of dermatitis, lesions, and injuries, such as bruising and scratching due to agglomeration of birds (Mendes et al 2010). It reduces carcass performance and yield because of lower feed and water intake which leads to lower body weight gain and higher incidence of injury. It results in rejection of these parts in the slaughterhouse (De Jong et al 2014).

The amount and severity of the scratches seem to be affected according to the stocking density of the broilers. Garcia et al (2002), for example, found average values of 15.8 , 20.0 and $25.6 \%$ of scratches in broilers reared at densities of 10,13 and $16 \mathrm{birds} / \mathrm{m}^{2}$, respectively.

The stocking density may have a positive correlation with the incidence of breast burn and scratches. Because a higher stocking density is related to a lower degree of warping which results in greater exposure of the abdominal skin and contributes to the development of callus and scratches. The birds walk less and spend more time lying on the litter, then it leads to the development of callus. Because of the smaller area, birds are prone to climb, disturb and scratch other birds to access the feeders and drinkers (Harris et al 1978; Allain et al 2009).

There are problems related to high stocking densities and thermal discomfort during broiler raising. According to Bessei (2006), heat transfer from the surface of the litter to the airspace is inhibited when the area is covered by many birds. But it should be considered that the level of litter compaction is also an impediment to the heat exchange between the litter and the air, because it impairs convection and evaporation, and it can contribute to the thermal stress in the broilers. Higher stocking densities are associated with higher environmental temperatures. It may affect the BEA, especially, when the farm has an inadequate environmental control and it is unable to provide thermal comfort for the birds which it may favor the incidence of scratches on them (Pilleco et al 2011).

\section{Design of farm facilities and thermal comfort}

The design of poultry house is related to the climatic conditions exposed to broilers during the growth period. However, it is necessary to study the relationship of the birds with the environment. It should be integrated with animal behavior, birds' physiology, basic concepts of the environment and production systems (Abreu and Abreu 2011).

Thermal comfort is an issue of extreme importance as it is related to the welfare and performance of birds. Although broilers are capable of regulating body temperature, approximately $80 \%$ of the energy obtained from the feed is used to maintain homeothermy and the remaining of the energy is used for other activities (Abreu and Abreu 2011).

Broilers need to be reared in facilities that provide thermal-neutral zones and attend health and nutritional requirements to guarantee welfare and performance of broilers (Baêta and Souza 1997). It is a result of their physiological peculiarity, which eliminates up to $70 \%$ of the sensible heat by radiation, conduction, and convection - It is influenced by the environmental temperature - while latent (or insensible) heat loss occurs by evaporation through the skin and respiratory system - where the relative humidity of the air assumes great importance (Abreu and Abreu, 2011).

It has been proven that poultry houses with high temperatures ranging from $26.7^{\circ} \mathrm{C}$ to $36 \pm 1.0^{\circ} \mathrm{C}$ may affect the health of broiler chickens, as it was shown by Olanrewaju et al (2010) and Quinteiro-Filho et al (2010).

In general, thermal stress induces activation of the hypothalamic-pituitary-adrenal axis, and it is responsible for the negative (catabolic) effects usually observed in the performance and immune function of broilers. According to Rao et al (2013), the relative weight of the lymphoid organs and their morphology are often used to estimate the immunity of broiler chickens to adverse situations.

One of the indicative of thermal stress, or thermal comfort assessment, is the measurement of the specific enthalpy of air expressed as the amount of thermal energy (heat) in $\mathrm{kJ}$ contained in $1 \mathrm{~kg}$ of dry air. This index is used to quantify and classify the thermal discomfort of broilers, which they may have their physiological responses and performance 
affected, as described by Rodrigues et al (2010) and Damasceno et al (2010).

In situations where the amount of heat from outside air

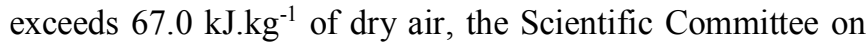
Animal Health and Animal Welfare of the European Union (Scahaw 2000) recommends that additional measures should be taken in the facilities. In general, it is proposed to increase the rate of ventilation, reduction of feed supply, cooling drinking water and nebulization until the relative air humidity does not exceed $80 \%$ within the aviary.

Broilers are greatly affected by environmental thermal conditions. Therefore, it is fundamental to integrate the farm management with this specific knowledge to promote improvement in the quality of life. Moura (2001) expressed that animals can present high prostration and mortality rates depending on the magnitude and duration of thermal stress, which it is contradictory to the aims of the producer and the poultry industry.

\section{Final Considerations}

The challenges of BEA in the poultry industry currently are diverse, among them the productivity losses are related to the zootechnical indexes, carcass lesions, mortality rate and meat quality defects. Besides the economic relevance, they can serve as indicators of broilers welfare and health, as well as it indicates how the birds were raised. Then they can trace the origin of problems production and minimize the economic losses.

BEA is multifactorial, so several aspects of broilers production are interrelated and related. It represents the complexity and importance of this subject in modern poultry farming, and the necessity for more complete studies involving the various stages of broiler production.

\section{Conflict of Interest}

The authord declare no conflict of interest.

\section{References}

Abreu VMN, Abreu PG (2011) Os desafios da ambiência sobre os sistemas de aves no Brasil. Revista Brasileira de Zootecnia 40:1-14.

Allain V, Mirabito L, Arnould C, Colas M, Bouquin Le S, Lupo C, Michel V (2009) Skin lesions in broiler chickens measured at the slaughterhouse: relationships between lesions and between their prevalence and rearing factors. British Poultry Science 50:407-417.

Alvino GM, Archer GS, Mench JA (2009) Behavioural time budgets of broiler chickens reared in varying light intensities. Applied Animal Behaviour Science 118:54-61.

Baêta FC, Souza CF (1997) Ambiência em edificações rurais: conforto animal. Editora UFV, Viçosa.

Bessei W (2006) Welfare of broilers: a review. World's Poultry Science Journal 62:455-466
Bilgili SF (2009) Influence of bedding material on footpad dermatitis in broiler chickens. The Journal of Applied Poultry Research 18:583589.

Bilgili SF (1990) Broiler quality: grades are posted. Broiler Industry 53:32-40.

Broom DM (1986) Indicators of poor welfare. British Veterinary Journal 142:524-526.

Broom DM, Reefmann N (2005) Chicken welfare as indicated by lesions on carcases in supermarkets. British Poultry Science 46:407414.

Collett SR (2012) Nutrition and wet litter problems in poultry. Animal Feed Science and Technology 173:65-75.

Costa MJ, Grimes JL, Oviedo-Rondón EO, Barasch I; Evans C, Dalmagro M, Nixon J (2014) Footpad dermatitis severity on turkey flocks and correlations with locomotion, litter conditions and body weight at Market age. Journal of Applied Poultry Research 23:1-12.

Damasceno FA, Yanagi Jr T, Lima RR, Gomes RCC, Moraes SRP (2010) Avaliação do bem-estar de frangos de corte em dois galpões comerciais climatizados. Ciência e Agrotecnologia 43:1031-1038.

Dawkins MS, Layton R (2012) Breeding for better welfare: genetic goals for broiler chickens and their parents. Animal Welfare 21:147155.

De Jong IC, Gunnink H, Harn JV (2014) Wet litter not only induces footpad dermatitis but also reduces overall welfare, technical performance, and carcass yield in broiler chickens. Journal of Applied Poultry Research 23:51-58.

De Jong IC, Lourens A, Van Harn J (2015) Effect of hatch location and diet density on footpad dermatitis and growth performance in broiler chickens. The Journal of Applied Poultry Research 24:105114.

Dunlop MW (2015) The multidimensional causal factors of 'wet litter' in chicken-meat production. Journal of environmental management 562:766-776.

European Commission (2007) Directive 2007/43/EC of 28 June 2007. Accessed on: December 28, 2016.

Estevez I (2007) Density Allowances for Broilers: Where to Set the Limits? Poultry Science 86:1365-1272.

Federici JF, Vanderhasselt R, Sans ECO, Tuyttens FAM, Souza APO, Molento CFM (2016) Assessment of Broiler Chicken Welfare in Southern Brazil. Revista Brasileira de Ciência Avícola 18:133140.

Frankenhuis MT, Vertommen MH, Hemminga H (1991) Influence of claw clipping, stocking density and feeding space on the incidence of scabby hips in broilers. Broiler Industry 32:227-230.

Garcia RG, Mendes AA, Garcia EA, Nääs IA, Moreira J, Almeida ICL, Takita TS (2002) Efeito da densidade de criação e do sexo sobre o empenamento, incidência de lesões na carcaça e qualidade da carne de peito de frangos de corte. Revista Brasileira de Ciência Avícola 4:1-9.

Harris GC, Musbah Jr M, Beasley JN, Nelson GS (1978) The development of dermatitis (scabby-hip) on the hip and thigh of broiler chickens. Avian diseases 22:122-130.

Kjaer JB, Su GU, Nielsen BL, Sorensen P (2006) Footpad dermatitis and hock burn in broiler chickens and degree of inheritance. Poultry Science 85:1342-1348.

Kristensen HH, Perry GC, Prescott NB, Ladewig P, Ersbøll AK, Wathes CM (2006) Leg health and performance of broiler chickens 
reared in different light environments. Britsh Poultry Science 47:257263.

Mendes AS, Reffati R, Restelatto R, Paixão SJ (2010) Visão e iluminação na avicultura moderna. Revista Brasileira de Agrociência 16:5-13.

Menzies FD, Goodall EA, Mcconaghy A, Alcorn MJ (1998) An update on the epidemiology of contact dermatitis in commercial broilers. Avian Pathology 27:174-180.

Moreira J, Mendes AA, Garcia RG, Nääs IA, Miwa I, Garcia EA, Takita TS, Almeida ICL (2001) Efeito da densidade de criação e do nível de energia da dieta sobre o desempenho e rendimento de carcaça em frangos de corte. Revista Brasileira de Ciência Avícola $3: 39$.

Moura DJ (2001) Ambiência na Produção de Aves de Corte. In: Silva IJO (ed) Ambiência na Produção de Aves em Clima Tropical, Piracicaba, pp 75-148.

Nagaraj M, Wilson CAP, Saenmahayak B, Hess JB, Bilgili SF (2007) Efficacy of a litter amendment to reduce pododermatitis in broiler chickens. The Journal of Applied Poultry Research 16:255-261.

New Zealand (2012) National Animal Welfare Advisory Committee. Code of welfare 2012 (meat chickens) under section 75 of the Animal Welfare Act 1999, 2012. Accessed on: February 01, 2015.

Olanrewaju HA, Purswell JL, Collier SD, Branton SL (2010) Effect of ambient temperature and light intensity on physiological reactions of heavy broiler chickens. Poultry Science 89:2668-2667.

Pilleco M, Almeida ICLP, Tabaldi LA, Nääs IA, Garcia RG, Caldara FR, Alves MCF, Felix GA (2011) Influence of genetic strain and season on back scratch lesions in broilers. Revista Brasileira de Ciência Avícola 13:241-245.

Proudfoot FG (1973) Response of broilers to variations in waterer, feeder, and floor space under continuous and intermittent photoperiods. Canadian Journal of Animal Science 53:349-354.

Quinteiro-filho WM, Gomes AVS, Pinheiro ML, Ribeiro A, Ferrazdepaula V, Astolfi-ferreira CS, Ferreira AJP, Palermo-neto J (2010) Heat stress impairs performance parameters, induces intestinal injury, and decreases machophage activity in broiler chickens. Poultry Science, 89:1905-1914.

Rao SVR, Prakash B, Raju MVLN, Panda AK, Poonam S, Murthy OK (2013) Effect of supplementing organic selenium on performance, carcass traits, oxidative parameters and immune responses in comercial broiler chickens. Asian-Australasian Journal of Animal Sciences 26:247-2562.

Rodrigues VC, Silva IJO, Vieira FMC, Nascimento ST (2010) A correct enthalpy relationship as thermal comfort index for livestock. International Journal of Biometeorology 55:455-459.

Saraiva S, Saraiva C, Stilwell G (2016) Feather conditions and clinical scores as indicators of broilers welfare at the slaughterhouse. Research in Veterinary Science 107:75-79.

Scahaw (2000) Scientific Commitee on Animal Health and Animal Welfare. The welfare of chickens kept for meat production (broilers). Accessed on: March 13, 2017.

Shepherd EM, Fairchild BD (2010) Footpad dermatitis in poultry. Poultry Science 89:2043-2051.

Switzerland (2011) Animal Welfare Ordinance. Accessed on: February 02, 2015.

Tsiouris V, Georgopoulou I, Batzios C, Pappaioannou N, Ducatelle $\mathrm{R}$, Fortomaris $\mathrm{P}$ (2015) High stocking density as a predisposing factor for necrotic enteritis in broiler chicks. Avian Pathology 44:59-66.

Van Der Hoeven-Hangoor E, Rademaker CJ, Paton ND, Verstegen MW, Hendrik WH (2014) Evaluation of free water and water activity measurements as functional alternatives to total moisture content in broiler excreta and litter samples. Poultry Science 93:1782-1792.

Vestergaard KS, Sanotra GS (1999) Relationships between leg disorders and changes in behaviour of broiler chickens. Veterinary Record 144:205-209

Welfare Quality (2010) The assessment of animal welfare on broiler farms [Report 18]. Accessed on: December 29, 2016. 